\title{
Analysis of professional competences formation among teacher-psychologists in the context of Federal State Educational Standards implementation
}

\author{
Fatimet P. Khakunova* (a), Asya K. Bersirova (b), Nurbyi Kh. Khakunov (c), \\ Elena V. Vorobyova (d)
}

(a), (b), (c) Adyghe State University, 385000, Maykop (Russia), 218, Pervomayskaya street, pedagog-psycholog84@mail.ru

(d) Don State Technical University, 344000, Rostov-on-Don ( Russia), 1, Gagarin square, evorob2012@yandex.ru

\begin{abstract}
Formation of professional competences and development of achievement indicators in the context of implementing the Federal State Educational Standards aims at training viable graduates prepared to: take part in both development and implementation of personal development and socialization programs aimed at achieving personal educational results in both curriculum and extra-curriculum activities according to the Federal State Educational Standards requirements; perform psychological and pedagogical follow-up procedures in the context of main and supplementary educational programs; provide psychological evaluation and consult the subjects of the education process; conduct correctional and developmental activities with children and students, including rehabilitation and recovery procedures.

Thus, the aims of the study are: to analyze the experience in professional competencies formation in training teacherpsychologists in the context of Federal State Educational Standards implementation; elicit and experimentally verify professional competency achievement indicators (Bachelor of Arts degree) and the effectiveness of success motivation development as the main condition of forming professional competency in future teacher-psychologists. This article addresses the experience of Pedagogics and Psychology Department of Adyghe State University. Considering that professional competencies achievement indicators are viewed as a "knowledge-skills-abilities" triad, the research had two stages. The first stage estimated the theoretical evaluation of knowledge, the second dealt with evaluating skills and abilities. We also suggested that successful professional competency formation in the context of Federal State Educational Standards implementation can be attributed to the success motivation development in future teacherpsychologists.
\end{abstract}

Keywords: professional standard, educational standard, teacher-psychologist, professional competences, success motivation.

(C) 2021 Fatimet P. Khakunova, Asya K. Bersirova, Nurbyi Kh. Khakunov, Elena V. Vorobyova

${ }^{*}$ Corresponding author. E-mail: pedagog-psycholog84@mail.ru 
This is an open access article distributed under the terms of the Creative Commons Attribution License (CC BY 4.0), which permits unrestricted use, distribution, and reproduction in any medium, provided the original author and source are credited.

Published by Kazan federal university and peer-reviewed under responsibility of IFTE-2021 (VII International Forum on Teacher Education

\section{Introduction}

Nowadays the practical endeavours of a teacher-psychologist within the education system are undergoing significant transformations, out of the necessity of increasing their quality standards for the new type of the educational environment (Korytova \& Korytova, 2018). The professional functions and the range of areas of professional activity of a teacher-psychologist have expanded, with the addition of: psychological expertise (assessment of comfort and safety of educational environment, psychological prevention aimed at preserving psychological health of the students; providing psychological and pedagogical assistance to persons with disabilities, persons who have difficulties in mastering educational programs, in development and adaptation and their consequent psychological counselling). This led to the emergence of new tasks in the professional training of teachers-psychologists and significant correlation of the existing content of the competence model of engagement in higher education. The peculiarity of the introduced federal state educational standard of higher education 3++ (FSES VO 3++) is the absence of professional competencies and the need for each educational organization to independently design these competencies in accordance with their own professional standard as well as determine the content of educational programs aimed at the formation of these competencies. While correlating the requirements of FSES VO $3++$ in the field of "Psychological and pedagogical education", the orientation "Psychology of education" with the professional standard "Teacher-psychologist" we have defined and introduced the following professional competences into the curriculum (Table 1).

In developing the curriculum and determining the content of educational modules, we primarily focused on the compliance with the requirements of FSES 3++ and the professional standard "Educational psychologist (psychologist in education)" in terms of competence formation and determination of indicators of their achievement. The said competency model of professional training of educational psychologists involves prominent specialists in its development and implementation, with the experts of the educational program in the direction of "Psychological and pedagogical education" being the heads of educational institutions.

Notably, the competency-based approach implemented in Russian higher education creates a number of issues associated with the assessment of professional competence development levels. 
The indicators of competence development are the learning outcomes in the categories "to know", "to be able to", and "to master". We understand professional competence as the ability to perform professional activities that can be tested in the process of work activities. Therefore, we believe that in the process of learning activity it stands to reason to check the set of professional knowledge, skills, and abilities as a result of learning, as a readiness to perform professional functions.

We assume that in professional development of a future teacher-psychologist the motivation to achieve success acts as an important factor of successful mastering of the program. If success achievement motivation and failure avoidance in the conditions of learning activity is a marker of success, then perhaps the dependence of learning efficiency on the structure of dominant motivation of students can be traced. Students with dominant success achievement motivation should perform well, distinguished by the desire to acquire new professional knowledge, competitiveness and professional self-improvement.

Thus, both the modernization of higher education and the professional standard "Educational psychologist (psychologist in education)" focus on the formation of modern professional competencies in future educational psychologists, which requires designing an educational environment capable of motivating to achieve professional expertise (Volkova, Kosheleva, Bogdanovskaya \& Khoroshih, 2017). The implementation of "Educational psychologist (psychologist in education)" professional standard actualizes the problem of developing new models and content of training in the professional development of psychological and pedagogical staff.

Formation of professional competencies and development of indicators of their achievement in the conditions of implementation of the federal state educational standard, is aimed at preparing a competitive graduate who is ready to: participate in the design and implementation of the program of education and socialization of students aimed at achieving personal educational results in educational and extracurricular activities in accordance with the requirements of the federal state educational standard of general education; carry out psychological and pedagogical support of the implementation of basic and additional educational programs; conduct psychological diagnosis of and counselling for the subjects of educational process; implement corrective and developmental work processes with children and students, including remediation and rehabilitation activities.

\section{Purpose and objectives of the study}

Based on the above, the purposes of the study are: 
1) to analyze the research experience in professional competencies formation in training teacherpsychologists in the context of Federal State Educational Standards implementation;

2) to study the effectiveness of success motivation development as the main condition of forming professional competency in future teacher-psychologists

Objectives of the study:

- to determine the state of the problem under study in both psychological and pedagogical theory;

- to reveal the peculiarities of professional competence formation in the conditions of implementation of the Federal State Educational Standard of higher education $3++$ in the training of teacherpsychologists;

- to identify and experimentally verify the indicators of achievement of professional competences (bachelor level);

- to determine the students' success motivation level.

The object of this study: the process of professional training of bachelors in the direction of "Psychological and Pedagogical Education"

The subject of the study: analysis of the formation of professional competencies of teacherspsychologists in the conditions of implementation of the Federal State Educational Standard of higher education $3++$.

\section{Literature review}

There are many publications devoted to the issue of competence approach implementation in education (Bogolyubov, Bergman, Borytko, Goncharova, Zeer, Lednev, Nikandrov, Khutorskoy, Churakova, Fishman). There are different approaches as to the definition of the term "competence". The notion of "competence" is defined not only as a set of abilities, knowledge and skills, but rather as an ability to perform tasks at a high level by applying a system of knowledge, skills, abilities and mental qualities combined. Zeer understands competence as meaningful generalizations of theoretical and empirical knowledge represented in the form of concepts, principles, sense-forming regulations, as well as generalized acting patterns providing productive performance of professional activities (Zeer, 2005). 
According to Sergeev, competences are a combination of such elements as skill, knowledge and experience, providing in total the ability to solve the set practical tasks in various spheres of life and professional activities (Yarmakeev, 2010). Goncharova defines the concept in question as a complex structure consisting of various elements and notes that all in all in generalized form competency can be defined as a property, while competence in itself is the possession of this property, which manifests itself in practical activities (Goncharova, 2007). According to Khutorskoy, competence is an alienated, predetermined social requirement (norm) to educational training of a student, which is necessary for their effective productive activity in a certain sphere. (Khutorskoy, 2003).

Some researchers characterize professional competence of a teacher-psychologist as a system of personal and professional characteristics - special readiness (as a result of university training, postgraduate additional training for professional activity); qualification in activity (result of mastering technologies of psychological and pedagogical activity in practice); organizational activity competence (result of continuous professional education and practical activity) (Zamorskaya \& Kosyrev, 2004). As scientists note, professional qualities - competences - allow the teacher-psychologist to solve problems effectively in dynamic conditions of a professional activity. Formation and development of professional competences occurs in the processes of continuous professional education and practical activity (Asadullin \& Galiullina, 2013). In foreign literature, the term 'professional competence' is noted as subject-oriented competence and stands for specialist knowledge in a specific subject area (Beelisle, Linard, Rey, Le Booterrf, Turkal, Guiqnon, Joras)

Henner believes that professional competences include professional knowledge, abilities, skills (KAS). Or professional competence is a category separate from professional knowledge and skills and existing on a par with them (Henner, 2018). In connection with this, he compares the law "On Education in the Russian Federation" where education is defined as "a set of acquired knowledge, abilities, skills, values, activity experience and competencies of a certain scope and complexity (Education Law, Art. 2 p. 1) and the Federal State Educational Standard, which should reflect the totality of the obligatory requirements for education of a certain level and (or) for a profession, specialty and field of training according to Article 2, clause 6 of the Law on Education and further notes that the existing standards set requirements only for competences and contrary to the provisions of the Law, do not include professional knowledge, abilities and skills in the obligatory results of education”. (Henner, 2018).

A number of researchers (Yelina, Kovtun, Rodionova) note that due to the need to formulate professional competencies in educational programs, there may be no requirements for professional knowledge and skills of university graduates (Elina, Kovtun, Rodionova, 2015). 
This situation creates certain difficulties in assessing and monitoring learning outcomes, including the assessment of the formation of professional competencies, as if during the development of educational programs, the activity of the teacher on the interim forms of certification is reduced to the verification and assessment of professional knowledge and skills.

Despite the rather extensive discussion of this problem, there is still no straightforward approach to the competence education model. Furthermore, on the correlation of professional competencies and professional knowledge, skills and abilities, while there are numerous discussions in progress, there is no unified position concerning the definition thereof. This aspect complicates the development of effective criteria for assessing professional competencies in the learning process even further. One of the indicators contributing to the formation of students' professional competencies is the success motivation.

Success motivation constitutes the desire for success, high results in an activity. Murray was the first to distinguish this type of motivation and gave the following definition to the term: "to cope with something difficult. To cope with, manipulate or organize physical objects, people or ideas. To do this as quickly and as independently as possible. Overcome obstacles and reach higher levels. Outperform oneself. Compete with others and surpass them. Increase one's self-esteem via the successful application of one's abilities" (Rozhkov, 2014). Furthermore, according to Heckhausen, achievement motivation can be defined as an attempt to increase or maintain a person's highest possible ability in all kinds of activities (Heckhausen, 2003).

In national psychology, one of the most significant authors on the problem of motivation is Leontiev, who represents the activity approach. He writes that "in modern psychology, everything that constitutes the socalled internal forces of behavior, everything that actualizes human activity, is generally called a motive" (Leontiev, 2000). He himself presents the following definition of a motive: "it is the objective thing that prompts and directs activity, answering this or that need, specifying a need or, naturally, satisfying a need".

The questions of success achievement motivation development became a subject of research of many scientists in the field of psychology (Biryukova, Gordeeva, Deryagina, Leontiev, Murray, Heckhausen). However, the specificity and conditions of development as well as interrelation in formation of professional competences of university students were not disclosed enough as of yet. As well as the process of development of success achievement motivation as a factor of formation of students' professional abilities is of special interest (Biryukova \& Smolyarchuk, 2014). 
However, achievement motivation as it were focuses on the ultimate end result obtained through one's own characteristics: achieving success or avoiding failure (Rozhkov, 2014).

\section{Methodology}

Research methods: literature analysis, reflective-system analysis; interrogatory (questionnaire, testing, expert assessment); observation, analysis of professional performance results among future teacherpsychologists, modeling, experiment, methods of mathematical statistics and processing. The study involved 57 1st and 2nd Year students of 44.03.02 Psychological and Pedagogical education, specification "Psychology of education" (Bachelor's degree).

Considering that the indicators of professional competence achievement are considered in the triad: "knowledge-abilities-skills", the study was conducted in two stages. The first stage determined the assessment of theoretical knowledge, and the second stage allowed us to assess the skills themselves. For this purpose, we carried out knowledge control using the fund of assessment tools of the disciplines that form professional competences. We analyzed the students' portfolios, as well as the results of introductory and design-technological practice. To study motivation to succeed in future teachers-psychologists we applied the method of diagnostics of personality to motivation to success originally introduced by Ehlers.

\section{Results}

We carried out the necessary analysis of the state of the problem under study in psychological and pedagogical theory, identifying the main approaches to the definition of the concepts: "competence" and "professional competence". The problem of assessing the formation of professional competence is outlined due to the lack of unequivocal criteria. It is supposed to control and assess the level of professional competence formation by a set of professional knowledge, skills and abilities as a result of training and readiness to perform professional functions in professional activity.

During our research we revealed the interrelation of the level of achievement of success motivation and success in mastering the educational program, and experimentally substantiated the necessity of formation of success motivation as a condition of professional formation as specialists.

In the first stage, we studied the compliance of the content of assessment tools and the main preliminary results for the disciplines implemented to form professional competencies. The main forms of current control of theoretical knowledge were studied and consequently analyzed. 
The assessment tools of the implemented disciplines in the direction of training 44.03.02 Psychological and Pedagogical Education, specification "Psychology of Education" (Bachelor's degree) were formed (based on the required knowledge, skills and abilities necessary to achieve certain professional competences).

Indicators of professional competences achievement are normally developed by each educational organization independently, and are obligated to reflect the requirements of the existing professional standard, as well as be verified by the assessment tools corresponding to the program of the implemented discipline. We have identified the following indicators in accordance with the studied disciplines of year 12 students:

Table 1. Professional competences and indicators of achievement

\begin{tabular}{|c|c|}
\hline Professional competence & Indicators of achievement \\
\hline \multirow[t]{3}{*}{$\begin{array}{l}\text { PC-1. The subject is able to } \\
\text { carry out psychological and } \\
\text { pedagogical diagnostics of } \\
\text { both the competence-based } \\
\text { and personal learning } \\
\text { outcomes of students }\end{array}$} & $\begin{array}{l}\text { PC-1.1. The subject knows: theory of psychodiagnostics, classification of } \\
\text { psychodiagnostic methods, their possibilities and limitations, their requirements; } \\
\text { methods of collecting, processing information, results of psychological observations } \\
\text { and diagnostics; ways of interpretation and presentation of results of } \\
\text { psychodiagnostic examination. }\end{array}$ \\
\hline & $\begin{array}{l}\text { PC-1.2. The subject can: carry out a diagnostic examination using standard tools, } \\
\text { including processing of results; carry out diagnostic work in order to identify the } \\
\text { level of readiness or adaptation of children and students to new educational } \\
\text { conditions; diagnose intellectual, personal and emotional-willful features that hinder } \\
\text { the normal course of development of learning and education. }\end{array}$ \\
\hline & $\begin{array}{l}\text { PC-1.3. The subject has mastered: educational diagnostic methods and techniques of } \\
\text { the psychologist; how to collect, analyze and interpret the obtained results. }\end{array}$ \\
\hline $\begin{array}{l}\text { PC-2. The subject is able to } \\
\text { advise and consult subjects } \\
\text { of the educational process } \\
\text { on psychological problems }\end{array}$ & $\begin{array}{l}\text { PC-2.1. The subject knows: Ethical standards for organizing counselling work; } \\
\text { modern organization and structure of joint individual activities for students } \\
\text { according to their developmental age norms. }\end{array}$ \\
\hline
\end{tabular}




\begin{tabular}{|c|c|}
\hline \multirow[t]{2}{*}{$\begin{array}{l}\text { of learning and } \\
\text { development. }\end{array}$} & $\begin{array}{l}\text { PC-2.2. The subject can: organize interactive activities with learners within the } \\
\text { framework of the educational process; provide individual and group counselling to } \\
\text { learners on the subject of learning process development; provide individual group } \\
\text { counselling to learners on learning development. }\end{array}$ \\
\hline & $\begin{array}{l}\text { PC-2.3. The subject has mastered: counselling for teachers, educators and parents } \\
\text { (legal representatives) on psychological problems in pupils' learning, education and } \\
\text { development. }\end{array}$ \\
\hline \multirow{3}{*}{$\begin{array}{l}\text { PC-3. The subject is able to } \\
\text { carry out organizational } \\
\text { activities in order to } \\
\text { provide necessary } \\
\text { psychological support for } \\
\text { the education, development, } \\
\text { upbringing and } \\
\text { socialization processes of } \\
\text { children and adolescents }\end{array}$} & $\begin{array}{l}\text { PC-3.1. The subject knows: the basics of age and pedagogical psychology, methods } \\
\text { used in pedagogy and psychology; methods of organizational and methodological } \\
\text { support for the main educational programs }\end{array}$ \\
\hline & $\begin{array}{l}\text { PC-3.2. The subject can: both select and apply the necessary methods and tools for } \\
\text { the development, education and socialization of adolescent children }\end{array}$ \\
\hline & $\begin{array}{l}\text { PC-3.3. The subject has mastered: teaching techniques, discussion and interactive } \\
\text { forms of teaching }\end{array}$ \\
\hline \multirow[t]{3}{*}{$\begin{array}{l}\text { PC-4. The subject is able to } \\
\text { diagnose, assess and } \\
\text { monitor the psychosocial } \\
\text { status of the minor's } \\
\text { educational neglect and } \\
\text { rehabilitative potential }\end{array}$} & $\begin{array}{l}\text { PC-4.1. The subject knows: legislation on the education and guardianship of minors, } \\
\text { additional guarantees, social support for orphans and children left without parental } \\
\text { care, social services for children with disabilities and other regulatory legal } \\
\text { documentation in the area of psychological, pedagogical and rehabilitative } \\
\text { assistance for minors, legislation on personal data protection. Techniques for } \\
\text { monitoring and evaluating the results of socio-psychological and socio-pedagogical } \\
\text { rehabilitation. }\end{array}$ \\
\hline & $\begin{array}{l}\text { PC-4.2. The subject can: analyze the reasons for referring a young person to } \\
\text { rehabilitation, interact with members of the rehabilitation team at the social health } \\
\text { service and other organizations about holistic rehabilitation for the benefit of the } \\
\text { rehabilitated person. }\end{array}$ \\
\hline & $\begin{array}{l}\text { PC-4.3. The subject has mastered: the basics of diagnosing and monitoring the } \\
\text { dynamics of psychosocial status, pedagogical neglect and the rehabilitative potential } \\
\text { of a minor. }\end{array}$ \\
\hline
\end{tabular}


According to the results of the analysis of the formation level of professional competencies, $35.5 \%$ of the respondents demonstrated a high level, $51.1 \%$ of the respondents showed an average level of competency acquisition and $13.4 \%$ of the students had a threshold level of professional competency formation.

- the ability to provide psychological and pedagogical support for the implementation of basic and additional educational programs;

- the ability to apply methods of psychological diagnostics;

- the ability to consult the subjects of the educational process.

In order to study the indicators of achievement of professional competencies, we analyzed the students' portfolios, as well as the reports of introductory and design-technological practice. The analysis of practice reports (practice diary, notes of the lessons conducted, training sessions, results of psychodiagnostic methods, individual work with students, work with parents, vocational guidance work with high school students, practice report - reflection of own professional activity, student questioning, interview, observation of students during the practice) show that the main problems faced by most students during the period of the study difficulties in positioning oneself as a teacher-psychologist are distributed as follows $58 \%$; difficulties in interpersonal interaction (both with students and with teachers and students' parents (sometimes there are difficulties in organizing students' activities, difficulties associated with the students' individual psychological features) - 34\%; the ability to analyze the activities of teachers and students using the proposed schemes, to make psychodiagnosis - 43\%; the ability to plan their activities and choose the material, methods and tools appropriate for the learning process $-35 \%$. the ability to organize the activity of students (collective, group, individual) - 33\%; the ability to establish relationships, andlor contacts with students, teachers, colleagues, parents of students - 49\%; the ability to use modern educational technologies in their work, including ICT - 23\%; the ability to create an atmosphere of goodwill and cooperation in the process of communication - $26 \%$; the ability to analyze their psychological and pedagogical activity, the ability to reflect $-31 \%$.

The level of academic achievement based on the analysis of current monitoring and the results of interim assessments, showed that the absolute level of achievement amounted to $83 \%$ and the qualitative level of achievement to $62 \%$. Such high indicators may exhibit the success of the process of mastering the basic professional educational program in the field of training 44.03.02 Psychological and Pedagogical Education, specification "Psychology of Education" (Bachelor's Degree) in accordance with FSES 3++. Namely, part of the disciplines formed by the participants of educational relations as well as a manifested increase in credits is largely in favor of practical classes and training practices. 
We have also surmised that successful formation of professional competences in the conditions of implementation of the federal state educational standard will be facilitated by the development of success motivation in future teachers-psychologists. We consider achievement motivation as an integrative characteristic of student's personality orientation while striving to achieve success in learning activities, to develop professional intentions and life goals, to form prospective plans for their achievement, which becomes an inherent condition of student's professional growth. The more knowledge is transformed into skills and abilities, the higher the professional motivation. To identify the level of students' motivational orientation to achieve success, we used the "Personality Diagnostic Methodology for Success Motivation" by Ehlers. The results of the survey showed that the majority of respondents have an average level of success motivation (49.7\%): they avoid failure, but nonetheless are sometimes willing to take risks. $11.4 \%$ of respondents with a high level of achievement motivation, show persistence and purposefulness. And only $7.2 \%$ of students have a dominant motivation to avoid failure.

The analysis of the results of the study of failure avoidance motivation according to T. Ehlers' methodology showed that $34.7 \%$ of students have got low level of failure avoidance motivation, $25.6 \%$ of students have got medium level of failure avoidance motivation, high $-29.5 \%$ of students and "too high" $-10.2 \%$ of students respectively.

This suggests that they are oriented more towards avoiding failure than risk-taking, and are not characterized by a high expectation of success, all of which suppresses the motivation to succeed - to achieve a goal. Thus, learners aiming for success and willingness to achieve high performance in work are oriented towards overcoming obstacles, desire for self-improvement, competition and rivalry, realising their abilities and talents

\section{Discussion}

The introduction of FSES HE 3++ allows us to formulate with relative ease the professional competencies based both on the professional standard and labour market requirements, which is a more progressive form of training organization in comparison with the rigid list of PCs in FSES HE 3+. The transition to the new Federal State Educational Standard of higher education 3++ is carried out gradually, as standards for many areas of training are being approved. The absence of unified educational programs implies that the educational organization itself, without waiting for the release of the curriculum, should disclose and develop indicators of competence achievement by categories: to know, to be able, to master and, respectively, both work out and implement the list of disciplines that form said competences (Ignatyev, Alekseeva, Bogushevich, 2019). 
However, there remains an issue arising from the transformation of professional competencies into a dominant category distinct from professional knowledge and skills, which in its turn makes it problematic to measure professional competencies in a HEI setting.

One of the factors contributing to the formation of professional competencies is the level of motivation to achieve success. Thus, the students with high level of success achievement and desire to achieve high results in the learning process are focused on overcoming obstacles, desire to constantly improve themselves, to compete, to realize their abilities and talents which successfully affects the performance of professional functions in the work activity.

\section{Conclusion}

The study allows us to conclude that it is necessary to form the following professional competencies in the context of Federal State Educational Standards implementation while training teacher-psychologists: perform psychological and pedagogical support procedures in the context of main and supplementary educational programs; carry out organizational activities in order to provide necessary psychological support for the education, development, upbringing and socialization processes of children and adolescents; provide psychological evaluation and consult the subjects of the education process; conduct correctional and developmental activities with children and students, including rehabilitation and recovery procedures.

To ensure the formation of these competences we implemented the following subjects into the main professional educational program 44.03.02 Psychological and Pedagogical education, specification "Psychology of education" (Bachelor's degree, vocational subjects element):

"Psychology of deviant behavior", "Modern psychotechnologies", "Remedial function of a teacherpsychologist", "Psycho-consulting of the subjects of educational process", "Psycho-pedagogical support of educational process", "Social competency formation in students", "Psycho-pedagogical support of children with special needs", "Psychosexual development and sex education of children", "Psycho-pedagogical support of implementing main and supplementary educational programs", as well as student training and internship programs. Elicited achievement indicators of professional competences allow us to analyze the effectiveness of implementing professional competences in the context of Federal State Educational Standards of training teacher-psychologists. Estimating the success motivation levels point out the degree of readiness for conducting professional activities in future teacher-psychologists. 
The results of the study can be used in curricula development, praxis work programs implemented in higher education, the implementation of comparative studies in order to develop a methodology for the practical training of teacher-psychologists. We plan to study the professional competences formation among teacherpsychologists in the context of Federal State Educational Standards implementation in depth, after the subjects complete their Bachelor degrees. Moreover, we plan to investigate the alterations in success motivation levels while completing the course of the main professional educational program 44.03.02 Psychological and Pedagogical education, specification "Psychology of education" (Bachelor's degree).

\section{References}

Asadullin, R. M., \& Galiullina, R. Z. (2013). Towards the formation and development of teacher's professional competence. Bulletin of Chelyabinsk State University, (26 (317)), 120-123.

Atlyaguzova, E. I. (2012). Defining the Conceptual Framework for Implementing the Competency-Based Approach in Technical Specialist Training. Vestnik (Herald) of Samara State Technical University. Series: Psychological and Pedagogical Sciences, (2 (18)), 10-18.

Berufliche Kompetenzentwicklumg. Berlin. Dezember, 1999. 6'99.

Biryukova I. A. \& Smolyarchuk I. V. (2014). Motivation to achieve success as a factor in the development of students' professional qualities. Povolzhsky pedagogichesky vestnik, (l (2)), 56-62.

Deryagina L. E. \& Sherstennikova A. K. (2015). The role of dominant motivation in the success (failure) of learning activities and its relationship with personal and situational anxiety. Russian Journal of Education and Psychology, (12 (56)), 3-14.

Elina E. G., Kovtun E. N., Rodionova S. E. (2015). Competencies and learning outcomes: The logic of presentation in educational programs. Vysshee obrazovanie $v$ Rossii $=$ Higher Education in Russia. 1: 10-20. (In Russ.).

Goncharova N. L. (2007). Category "competency" and "competence" in modern educational paradigm // Collection of scientific works of NCFU. Series Humanitarian Sciences. 5.

Gordeeva T.O. (2006). Psychology of achievement motivation. M.

Heckhausen H. Motivation and activity (2003) [Electronic resource] / H.Heckhausen. - 2nd ed. electron. St.-Peter; M.: Smysl. 
Henner E. K. (2018). Professional knowledge and professional competences in higher education. Education and Science, 20 (2), 9-31.

Hutorskoy A.V. (2003).The key competences as a component of personality-centered education // Narodnoe Obrazovanie, 2, 58-64.

Korytova G.S., \& Korytova A.I. (2018). Implementation of professional standard "Teacher-psychologist" in educational establishments: structure and contents analysis. Pedagogical Review, (4 (22)), 123132.

Leontiev A.N. (2000). Lectures on General Psychology. M.

Murray H.A. (1938). Explorations in personality New York; Oxford Press

Rozhkov E.M. (2014). Motivation to achieve success and avoid failure in the works of native and foreign scientists//Current Science, 3, 31-34.

Sergeev I.S. (2004). Fundamentals of Pedagogical Activity. - SPb.: Piter.

Shevyrdyaeva K. S. (2015). The study of differences in the motivational sphere of university students studying in the field of psychology and pedagogy. Bulletin of Penza State University, (3 (11)), 1823.

Volkova E.N., Kosheleva A.N., Bogdanovskaya I.M., \& Khoroshih V.V. (2017). Model of professional competences and vocational qualification level assessment of teacher-psychologists in the context of professional standard "teacher-psychologist (psychologist in education)". Bulletin of Mininskiy University, (4 (21)).

Yarmakeev, I. E. (2010). Professional competence as the most important characteristic of personality and activity of modern specialist. Philology and Culture, (20), 291-297.

Zamorskaya, T. V. \& Kosyrev, V. N. (2004). Personality-professional development of a teacherpsychologist as the basis of his professional competence: methodology, state of the problem, basic concepts. Gaudeamus, 2 (6), 31-40.

Zeer, E. F. (2005). The competence approach to education. Education and Science, (3), 27-40. 